\title{
Tax structure and revenue instability: the Great Recession and the states
}

\author{
Howard Chernick $^{1 *}$, Cordelia Reimers ${ }^{2}$ and Jennifer Tennant ${ }^{3}$
}

\author{
* Correspondence: \\ howard.chernick@hunter.cuny.edu \\ ${ }^{1}$ Hunter College and the Graduate \\ Center, CUNY, New York, USA \\ Full list of author information is \\ available at the end of the article
}

\begin{abstract}
The Great Recession had the most severe impact on state tax revenues of any downturn since the Great Depression. We hypothesize that states with more progressive tax structures are more vulnerable to economic downturns, and that progressivity and income volatility may interact to amplify the recession's fiscal impact. We find that, while potential revenue exposure is greater in more progressive states, the most important source of variation was differences in income concentration and capital gains shares in the top 5 percent of taxpayers. Though the interaction between income volatility and high tax burdens at the top did produce large decreases in tax revenue in a few states, tax progressivity accounted for little of the overall interstate variation in revenue volatility.

JEL codes: $\mathrm{H} 24 ; \mathrm{H} 71$

Keywords: Tax volatility; Tax progressivity; Income distribution; Capital gains
\end{abstract}

\section{Introduction}

Stability of revenues is an important feature of sub-national revenue systems. Because spending obligations generally increase in recessions, and states and localities are sharply constrained in their ability to run deficits, the greater the volatility of revenues over the business cycle, the greater the pressure to cut spending and raise taxes during recessions, and the greater the incentive to expand spending commitments and cut taxes during recovery. Such instability reinforces the pro-cyclical impact of state and local budgets.

The two most important types of taxation used by U.S. states are taxes on consumption and personal income. In 2007, 49 percent of state tax revenues came from consumption taxes, and 32 percent from income taxes. The conventional wisdom is that consumption is more stable than income through the business cycle, implying that taxes on consumption are likely to be less volatile than taxes on income. However, consumption taxes are also widely assumed to be more regressive than income taxes, though incidence varies depending on the specific bases and rate structures and the time period of analysis (Institute for Taxation and Economic Policy 2009; Chernick and Reschovsky 1997). If these assumptions are correct, states face a potential tradeoff between vertical equity and revenue stability.

The Great Recession of 2007-2009 provides an important test case to examine the equity-stability tradeoff. This recession precipitated the sharpest decline in state tax revenues in the post-war period. Between fiscal years 2007 and 2010 nominal tax 
revenues declined by 7.6 percent. It was only in 2011, four years after the onset of the recession, that state taxes regained their prior nominal peak ${ }^{1}$. Though partially offset by increased federal aid, revenue reductions led to sharp decreases in state employment and state aid to local governments ${ }^{2}$. However, despite the depth of the aggregate decline, variation across states was considerable. Of the 48 contiguous states, 36 experienced nominal declines in state tax revenue, while 12 had increases ${ }^{3}$.

While the business cycle would be expected to exert an important influence on state tax revenues, the exceptionally large decline in revenues in the Great Recession, as well as in the 2001 recession, suggests that recession-related volatility may have increased over time. A potential source of increased volatility, both for federal and state tax revenues, is the secular increase in income concentration and capital gains receipt in the United States ${ }^{4}$. Because the share of income from capital gains rises with the level of income, increased income concentration has been accompanied by increased concentration of income from capital gains ${ }^{5}$. Given that capital gains are closely tied to the value of stock shares, and stock prices are more volatile than ordinary income, income from capital gains tends to be more cyclically volatile than ordinary income. This implies that incomes at the top of the distribution will be more cyclically sensitive than average income ${ }^{6}$. Increasing volatility of the tax base may in turn increase the sensitivity of state tax revenues to the business cycle. Moreover, volatility may be magnified in states with more progressive tax structures, as bigger changes in the tax base at the top end are amplified by higher tax rates applied to that income.

In this paper, we use the Great Recession as a test case to address the effect on state tax revenues of income concentration, capital gains receipt, and tax progressivity. Were the sharper drops in state tax revenues experienced in a number of states due mainly to greater income inequality, more capital gains receipt, and differences in state tax structure, or was the overall severity of the Great Recession the dominant force?

We first sort out the impacts on state tax revenue of shocks to income in different parts of the income distribution, tax burdens at those income levels, and the overall tax burden. We develop and implement the concept of "potential revenue exposure"; that is, the predicted change in revenue due to an income shock, given the state's tax structure, in the absence of policy offsets such as changes in tax rates. We use this concept to simulate the effect on revenue exposure of alternative counterfactual assumptions about income shocks, tax progressivity, and average tax rates. We then estimate regression models to investigate how the concentration of income and capital gains contributed to the shocks to income in the upper part of the income distribution, and to analyze the effects of tax progressivity versus income shocks on state tax revenues. While other papers have examined the role of base volatility and tax structure, our paper is the first to take systematic account of interstate differences in base volatility by income concentration and capital gains receipt, and the interaction between differential volatility and the distribution of state tax burdens by income level.

Our principal finding is that, while potential revenue exposure is greater in more progressive states, the most important source of interstate variation in revenue exposure in the Great Recession was not state tax structure, but differences in the importance of income concentration and capital gains income, as well as the state-specific severity of the recession. At the top end of the income distribution the interaction between sharp drops in income and high tax burdens can produce large decreases in tax revenue. 
However, tax progressivity accounts for very little of the overall interstate variation in revenue volatility during the 2007-2009 recession. At present these conclusions apply only to the most recent recession. However, our methodology could be readily applied to previous recessions, to determine whether the results generalize to other businesscycle induced fluctuations in state tax revenues.

The plan of the paper is as follows. Section 1 contains a brief literature review. Section 2 discusses the roles of income concentration, capital gains, and tax progressivity in revenue volatility. Section 3 presents the conceptual basis for calculating revenue exposure, the implementation of this concept for state taxes, and the comparison of revenue exposure to both the actual change in taxes and to counterfactual measures that remove the interstate variation in one factor at a time. Section 4 analyzes the change in the tax base, with a focus on changes in top-quintile AGI, while Section 5 analyzes actual revenue changes as a function of tax structure and changes in the tax base. Section 6 concludes.

\section{Literature review}

Prior research on state tax volatility has used panel data to estimate separate revenue elasticities for the major state taxes, attempting to distinguish between short- and longrun elasticities. Holcombe and Sobel (1996), using the period 1972-1993, find similar short-run elasticities with respect to personal income for the sales tax (1.3) and the income tax (1.4). In a recent summary of the literature, Dye (2004) emphasizes that both base and revenue elasticities with respect to changes in income differ across states.

Dye and McGuire (1991) take the personal consumption series from the National Income and Product Accounts and income changes by income class from the Current Population Survey to provide national estimates of changes in the sales and income tax bases over a 20-year period. These series are used to estimate national average responses of state sales and income tax revenues to the business cycle. Their income measure excludes capital gains, and does not take account of variation across states in the cyclicality of tax bases. They simulate the variability across states of state taxes under both broad and narrow sales tax bases, and both flat and highly progressive income tax structures. They find greater variability of the income tax under the progressive structure. Putting the sales and income tax results together, they conclude that state tax structure has an important impact on volatility. However, in his 2004 paper, Dye suggests that changing the mix of taxes would on average have little effect on state tax volatility. Bruce et al. (2006) find that the average long-run elasticity for income taxes is more than double that for sales taxes, but neither tax is universally more volatile. In contrast to Dye (2004), Seegert (2012) concludes that most of the increase in state tax volatility in the 2000's can be attributed to imbalance in state tax structures, defined as overweighting either sales or income taxes. None of the studies cited take into account differences across states in the elasticity of the tax base by income level.

\section{Income distribution and tax structure}

\section{A. Income inequality and capital gains}

Within the widely noted national increase in income inequality, there is considerable variation across states. In the state at the 90th percentile of income inequality (as measured by the share of a state's total adjusted gross income [AGI] received by the top 5 percent of 
taxpayers), the top 5 percent of taxpayers received 42 percent of total AGI in 2007, compared to 29.5 percent in the state at the 10th percentile.

The sharp drop in top incomes in the 2007-2009 recession was largely due to the importance of capital gains in the income of top taxpayers and the cyclical volatility of realized capital gains. Aggregate capital gains realizations declined by 95 percent between 2007 and 2009, from $\$ 913$ billion to $\$ 48$ billion $^{7}$. In contrast, total AGI declined 12.2 percent over this period (\$1.06 trillion), while personal consumption expenditures declined 1.9 percent (Internal Revenue Service various years; U.S. Dept of Commerce). Thus capital gains, though constituting only 10.5 percent of AGI in 2007, accounted for more than 80 percent of the total decline.

Capital gains income is highly concentrated in a relatively small number of tax returns. In 2007, over 80 percent of all capital gains were realized by the top 5 percent of taxpayers, of which about 38 percent were realized by the top one tenth of one percent of taxpayers (Lurie and Pearce 2012). While the share of capital gains realized by the top 5 percent of returns has remained relatively constant over time, the share of the top one tenth of one percent has both increased over time and fluctuated more during recessions. Of the 41 states with broad-based income taxes, 33 tax capital gains income at ordinary income tax rates, while 8 offer special tax breaks (Institute for Taxation and Economic Policy 2011). Hence, most capital gains income is taxed at the highest state marginal tax rate.

Given the volatility of capital gains income, a key point is that capital gains income varies in importance across states. Among the top 5 percent of filers in a state, the mean share of AGI from capital gains realizations in 2007 was 21 percent, but it ranged from 13 percent in West Virginia to 39 percent in Wyoming. ${ }^{8}$. If finer breakdowns were available, they would undoubtedly show even greater variation across states in the capital gains share for the top one percent or higher of a state's income distribution.

\section{B. State tax progressivity}

The progressivity of state tax systems also varies substantially across states. The tax burden for a given slice of the income distribution is defined as the sum of state and local taxes ultimately paid by a family with income equal to the average for that slice, divided by that average income ${ }^{9}$. Drawing on multiple years of data from the Institute for Taxation and Economic Policy (ITEP) of the Citizens for Tax Justice and other studies, Chernick (2005) shows that progressivity, defined as the ratio of the burdens on the top 5 percent of families to the bottom 20 percent, ranges across states by almost three to one. In 2007, according to the ITEP model, the burden on the top 5 percent of the income distribution ranged from 2.3 percent to 10.1 percent. Among the next 15 percent of taxpayers, the range was 4.5 percent to 12.7 percent $^{10}$. This variation, largely derived from differences in state income taxation, is potentially large enough to induce substantial variation in revenue impacts across states, from a given economic shock at the top end of the income distribution ${ }^{11}$.

\section{Revenue exposure}

\section{A. Conceptual approach}

The traditional approach to explaining volatility is to model overall changes in tax revenues over time as a function of the changes in the tax base for each individual tax - individual 
income tax, general and selective sales taxes, the corporation income tax and in a few states severance taxes - and the policy offsets which are imposed (Dye and McGuire 1991; Dye 2004). In contrast, we focus on the effects of differences in state income distributions, capital gains receipt, and state tax progressivity in a particular recession, with special attention to the top of the income distribution.

The change in tax revenue from an economic downturn can be decomposed as follows:

$$
\Delta \text { Tax Revenue }_{\mathrm{j}}=\Sigma_{\mathrm{q}}\left[\left(\Delta \text { Base }_{\mathrm{qj}} \cdot \text { Rate }_{\mathrm{qj}}\right)+\left(\text { Base }_{\mathrm{qj}} \cdot \Delta \text { Rate }_{\mathrm{qj}}\right)+\left(\Delta \text { Base }_{\mathrm{qj}} \cdot \Delta \text { Rate }_{\mathrm{qj}}\right)\right]
$$

where $q$ indexes slices of the income distribution, while $j$ indexes states. The base changes in (1) may be divided into a recession component and a policy offset:

$$
\Delta \text { Base }_{\mathrm{qj}}=\Delta \text { Base }_{\mathrm{qj}}, \text {,recession }+\Delta \text { Base }_{\mathrm{qj}} \text {, policy }
$$

The first term in (2) is the change in the tax base due to the recession, with policy unchanged. A state's revenue exposure is defined as

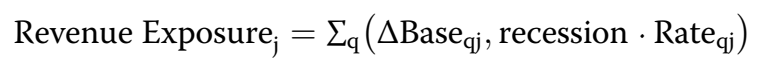

Recession-related changes in tax bases may be offset (or reinforced) by policy changes, which can affect both bases and rates. For example, states might expand the sales tax base, or raise marginal income tax rates ${ }^{12}$. The policy offset is equal to

$$
\text { Revenue Offset }{ }_{\mathrm{j}} \text {, policy }=\Sigma_{\mathrm{q}}\left[\Delta \text { Base }_{\mathrm{qj}}, \text { policy } \cdot \text { Rate }_{\mathrm{qj}}+\left(\text { Base }_{\mathrm{qj}}+\Delta \text { Base }_{\mathrm{qj}}\right) \cdot \Delta \text { Rate }_{\mathrm{qj}}\right]
$$

Note that "offset" includes all revenue generated by tax rate changes, applied to both the original tax base plus recession-related base changes, plus policy-related base changes applied to the original tax rates. Hence, the change in revenue may be rewritten as

$$
\Delta \text { Tax Revenue }_{j}=(3)+(4)=\text { Revenue Exposure }_{j}+\text { Revenue Offset }_{j}, \text { policy }
$$

\section{B. Empirical measure of revenue exposure}

To assess the fiscal effect of the recession via changes in the income distribution, we measure exposure as the product of the change in income by income segment and the state-specific tax burden on that segment. Based on available IRS data and our focus on the effect of income changes at the high end of the income distribution, families are divided into three income segments: the top 5 percent of tax filers, the next 15 percent, and the bottom 80 percent. To make large and small states comparable in scale, we divide by the number of federal income tax returns in 2007. The potential change in aggregate tax revenue per return equals the weighted average of the potential revenue change per return by income segment, where the weights are the shares of tax returns in each segment.

Our measure of revenue exposure for state j, computed for the years 2007-2009, is given by

$$
\text { Revenue Exposure }_{j}=\Sigma_{q=1,3}\left[t_{07 q j} \cdot\left(\Delta \text { Base }_{07-09 q j}\right) \cdot \text { ShareReturns }{ }_{\mathrm{qj}}\right]
$$

In expression (6), the subscript $q$ denotes the segment of the income distribution and $j$ denotes the state. The rate $t_{07 q}$ represents the effective tax burden on segment $\mathrm{q}$ in 2007, $\triangle$ Base $_{07-09 q}$ is the change in AGI in segment q from 2007 to 2009, and 
ShareReturns ${ }_{\mathrm{q}}$ is the share of federal tax returns in segment q. The empirical implementation of (6) is given by

$$
\begin{aligned}
& \text { Revenue Exposure }_{\mathrm{j}}=\left\{.05\left[\left(\mathrm{t}_{07 \mathrm{top} 5, \mathrm{j}} / \mathrm{t}_{07 \mathrm{avg}, \mathrm{j}}\right) \cdot \Delta \mathrm{AGI}_{07-09 \text { top } 5, \mathrm{j}} / \operatorname{Ret}_{07 \mathrm{top} 5, \mathrm{j}}\right)\right] \\
& +.15\left[\left(\mathrm{t}_{07 \mathrm{nxt15,j}} / \mathrm{t}_{07 \mathrm{avg}, \mathrm{j}}\right) \cdot \Delta \mathrm{AGI}_{07-09 \mathrm{nxt15,j}} /, \operatorname{Ret}_{07 \mathrm{nxt15}, \mathrm{j}}\right] \\
& \left.\left.+.80\left[\left(\mathrm{t}_{07 \mathrm{nxt80,j}} / \mathrm{t}_{07 \mathrm{avg}, \mathrm{j}}\right) \cdot \Delta \mathrm{AGI}_{07-09 \mathrm{nx} 800, \mathrm{j}} / \operatorname{Ret}_{07 \mathrm{nx} 800, \mathrm{j}}\right)\right]\right\} \cdot \mathrm{t}_{07 \mathrm{avg}, \mathrm{j}}
\end{aligned}
$$

Ret $_{07 \mathrm{qj}}$ is the number of federal tax filers in segment q of the AGI distribution in state $j$ in 2007. The average tax burden $t_{07 a v g, j}$ in (7) is the income share-weighted sum of the tax burdens; i.e.,

$$
\mathrm{t}_{07 \text { avg,j }}=\sum_{\mathrm{q}=1,3}\left[\mathrm{t}_{07 \mathrm{qj}} \cdot\left(\mathrm{AGI}_{07 \mathrm{qj}} / \text { Total } \mathrm{AGI}_{07 \mathrm{j}}\right)\right]
$$

The average tax burden $t_{07 a v g, j}$ may be thought of as representing the state's preferences for public services, while the progressivity measure, $t_{07 \mathrm{qj}} / \mathrm{t}_{07 \mathrm{avg}, \mathrm{j}}$, measures the state's distributional preferences. We retain $t_{07 a v g, j}$ in (7), even though it could be cancelled out of the equation, because it allows us to distinguish changes in progressivity from changes in the average tax burden in the simulations which follow.

\section{Construction of tax and income variables}

Effective tax burdens $\mathrm{t}$ by income quintile are produced by the 50 -state tax incidence model from the Institute for Taxation and Economic Policy (ITEP 2009) ${ }^{13}$. The model assigns taxes to families based on patterns of income and consumption. Changes in the tax base by income level within a state are measured by the 2007-2009 change in adjusted gross income (AGI) for that slice of the income distribution. The data source for AGI and number of tax returns by state is the published IRS Statistics of Income data by AGI bracket. We interpolated, as described below, to estimate AGI for the top 5, next 15, and bottom 80 percent of returns.

The ITEP measures tax burdens by simulating taxes paid based on the structure of state income taxes, the rates and coverage of general and specific sales taxes, and rates of the corporation income tax. Income taxes are assumed to be borne by taxpayers, while consumption taxes are mainly shifted forward to consumers. State corporate income taxes are assumed to be borne mainly by capital within the state, with some portion exported to residents of other states. The ITEP measures do not take account of taxes imported into or exported from a state ${ }^{14}$. Given the small amount of revenue most states raise from the corporation income tax, estimated tax burdens for the high end of the state's income distribution are largely a function of the structure of the personal income tax, including the top marginal rate, bracket widths, and the tax treatment of capital gains. Consumption tax burdens are assigned according to spending patterns by income class for taxed items, using the Consumer Expenditure Survey.

In addition to the tax burden estimates, the ITEP data also provide estimates of average family income by income-distribution slice by state for 2007. The slices are the first four quintiles, the next fifteen percent, the next four percent, and the top one percent. In contrast, the published IRS data provide AGI, realized capital gains income, and number of returns by AGI bracket, state, and year. The brackets are (in thousands): less than $\$ 50, \$ 50-\$ 75, \$ 75-\$ 100, \$ 100-\$ 200, \$ 200$ and above. To combine the IRS data on 
changes in income with the ITEP data on tax burdens, we need to express the IRS data in terms of percentiles. Given the share of returns that is in each AGI bracket, we use linear interpolation to assign a percentage of the AGI and capital gains amounts within each bracket to the respective percentiles ${ }^{15}$. However, we could not estimate AGI or capital gains amounts for the top one percent, because the open-ended top AGI bracket contains more than one percent of the returns in every state. A disproportionate share of the income and capital gains in this bracket belong to the top one percent, but we have no way of estimating what that share is, on a state-by-state basis. Given the particular importance of the top end of the income distribution for revenue changes, we therefore decided to collapse the ITEP data into three slices; the top 5 percent, the next 15 percent, and the bottom 80 percent $^{16}$.

Summary statistics and data sources for the components of revenue exposure, including tax burdens and changes in AGI by income slice, are given in Table 1. The table also includes summary data for variables used in the subsequent regression analysis of changes in AGI by slice of the income distribution, including capital gains shares and income shares, and changes in state tax revenues.

\section{Results of the fiscal exposure analysis}

Table 2 compares potential revenue exposure and change in actual revenue, for all states and for selected subsets ${ }^{17}$. (Hereafter, "revenue" refers to tax revenue, for the sake of brevity.) The table also shows tax progressivity (row 7), as measured by the ratio of the burden on the top 5 percent to the average burden. Column (1) highlights the wide range in the effect of the Great Recession on state tax revenues. While the mean change in state tax revenue per return was a drop of $\$ 138$, the standard deviation (\$582) is more than four times as large. The average percentage decline (row 3) was 3.1 percent, with a standard deviation (10.3) over three times as large as the mean ${ }^{18}$.

Table 1 Summary statistics of relevant variables $(\mathrm{N}=\mathbf{4 8})$

\begin{tabular}{|c|c|c|c|c|}
\hline Variable & Mean & Std Dev & Min & Max \\
\hline Change in total state tax revenue 2007-2009, per 2007 return & -138 & 582 & $-1,128$ & 2,596 \\
\hline Potential revenue exposure ${ }^{2}$ & -255 & 215 & -874 & 214 \\
\hline Change in AGl per return in top $5 \%$ of returns, $2007-2009^{3}$ & $-83,774$ & 46,787 & $-237,197$ & $-10,729$ \\
\hline Change in AGl per return in next $15 \%$ of returns, $2007-2009^{3}$ & $-5,257$ & 2,857 & $-11,571$ & 5,633 \\
\hline Change in AGl per return in bottom $80 \%$ of returns, $2007-2009^{3}$ & 1,108 & 787 & -821 & 2,938 \\
\hline Total state tax burden on top $5 \%, 2007^{4}$ & 0.066 & 0.019 & 0.023 & 0.101 \\
\hline Total state tax burden on next $15 \%, 2007^{4}$ & 0.085 & 0.016 & 0.045 & 0.127 \\
\hline Total state tax burden on bottom $80 \%, 2007^{4}$ & 0.093 & 0.014 & 0.060 & 0.116 \\
\hline Average state tax burden, $2007^{4}$ & 0.082 & 0.015 & 0.042 & 0.112 \\
\hline Share of total AGI in top $5 \%$ of returns, $2007^{3}$ & 0.338 & 0.046 & 0.278 & 0.486 \\
\hline Share of total AGI in next $15 \%$ of returns, $2007^{3}$ & 0.289 & 0.020 & 0.221 & 0.316 \\
\hline Capital gains share of AGI in top $5 \%$ of returns, $2007^{3}$ & 0.209 & 0.053 & 0.126 & 0.389 \\
\hline Capital gains share of AGI in next $15 \%$ of returns, $2007^{3}$ & 0.033 & 0.008 & 0.018 & 0.054 \\
\hline
\end{tabular}

Source notes:

${ }^{1}$ U.S. Census Bureau 2007 \& 2009.

${ }^{2}$ Authors' calculations (see Table 2, footnote 1).

${ }^{3}$ Internal Revenue Service various years and authors' calculations (see section 3C).

${ }^{4}$ Institute for Taxation and Economic Policy 2009. 
Table 2 Change in actual taxes vs. potential revenue exposure: high and low states

\begin{tabular}{|c|c|c|c|c|c|c|}
\hline & (1) & (2) & (3) & (4) & (5) & (6) \\
\hline & All states & $\begin{array}{l}5 \text { most } \\
\text { progressive } \\
\text { states }^{2}\end{array}$ & $\begin{array}{l}5 \text { most } \\
\text { regressive } \\
\text { states }^{3}\end{array}$ & $\begin{array}{l}5 \text { largest } \% \\
\text { decreases in } \\
\text { state taxes }{ }^{4}\end{array}$ & $\begin{array}{l}5 \text { largest \% } \\
\text { increases in } \\
\text { state taxes }\end{array}$ & $\begin{array}{l}8 \text { states with } \\
\text { high mineral } \\
\text { taxes }^{6}\end{array}$ \\
\hline $\begin{array}{l}\text { Change in total state tax } \\
\text { revenue ( } \$ \text { per return) }\end{array}$ & -138 & -400 & 232 & -782 & 1031 & 480 \\
\hline (Standard Deviation) & (582) & & & & & \\
\hline $\begin{array}{l}\text { Percent change in total state } \\
\text { tax revenue }\end{array}$ & -3.1 & -6.7 & 1.2 & -14.6 & 17.7 & 7.9 \\
\hline (Standard Deviation) & $(10.3)$ & & & & & \\
\hline Potential revenue exposure ${ }^{1}$ & -255 & -466 & -189 & -459 & -102 & -9 \\
\hline \multicolumn{7}{|l|}{$\begin{array}{l}\text { (Total state taxes, in } \$ \\
\text { per return) }\end{array}$} \\
\hline (Standard Deviation) & (215) & & & & & \\
\hline Progressivity: & 0.8 & 0.98 & 0.54 & 0.78 & 0.77 & 0.75 \\
\hline \multicolumn{7}{|l|}{$\begin{array}{l}\text { Burden on top 5\%/Average } \\
\text { burden }\end{array}$} \\
\hline Average tax burden & 0.082 & 0.084 & 0.057 & 0.08 & 0.071 & 0.079 \\
\hline \multicolumn{7}{|c|}{$\begin{array}{l}\text { Notes: } \\
\text { 'Defined as the weighted sum of the change in AGI 2007-2 } \\
\text { (i.e., top } 5 \text { percent, next } 15 \text { percent, bottom } 80 \text { percent), we } \\
{ }^{2} \text { California, New Jersey, Oregon, Delaware, Vermont. } \\
{ }^{3} \text { Washington, South Dakota, Wyoming, Nevada, Florida. } \\
{ }^{4} \text { Arizona, California, New Mexico, Florida, Connecticut. } \\
{ }^{5} \text { Wyoming, North Dakota, lowa, Indiana, Montana. }\end{array}$} \\
\hline
\end{tabular}

The fifth row of Table 2 shows potential revenue exposure. Mean exposure was almost twice as large as mean revenue change, while the standard deviation (215) is less than half that of actual revenue changes ${ }^{19}$. It is not surprising that actual revenue performance varies more than potential exposure, given that the exposure measure does not take account of changes in taxes that are heavily exported, including severance taxes on minerals (mainly oil and gas extraction) and taxes paid by out-of-state tourists $^{20}$. Tourism was strongly affected by the Great Recession, while oil and gas extraction activities increased dramatically due to technological developments in extraction techniques.

Figure 1 shows a scatter plot of actual revenue change against revenue exposure, for the states mentioned in Table 2, plus New York. Wyoming and North Dakota are clear outliers, due to the sharp increase in severance tax revenues in these two states. A comparison of California and New York is also instructive. While both had similarly large potential revenue exposures, the actual change in California was about equal to that exposure, whereas the actual change was much smaller in New York ${ }^{21}$.

The remaining columns of Table 2 show changes in actual revenue and revenue exposure for the top and bottom ten percent of states, ranked according to degree of progressivity (columns 2 and 3), largest increase or decrease in revenues (columns 4 and 5), and importance of severance taxes (column 6). As expected, both actual revenue decreases and potential revenue exposure are greater for the more progressive states. As shown in the third row of Table 2, revenues dropped by 6.7 percent for the 


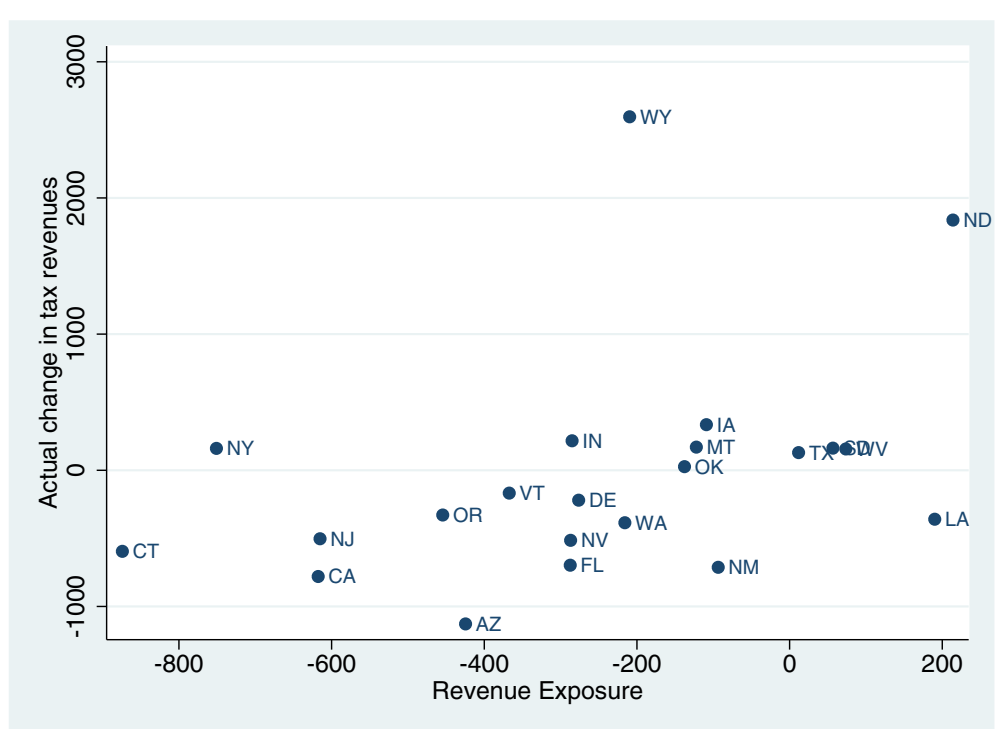

Figure 1 Potential revenue exposure vs. change in taxes, 2007-2009. The change in taxes is per 2007 federal tax return.

most progressive states, but went up by 1.2 percent for the most regressive group. Row 5 shows that potential revenue exposure is also much closer in value to the actual revenue change for the progressive states than for the regressive states and for the states with large declines than the states with large increases. Revenue exposure is negative (predicting a decline in tax revenues) for all four groups, whereas actual revenue changes were positive for the regressive states. This suggests that either policy offsets or changes in severance taxes and tourist taxes were more important for the regressive states and states with large increases. Three of the states with the largest revenue increases - Wyoming, North Dakota, and Montana - were heavily reliant on mineral taxation.

To summarize, among all states, particularly those with more progressive tax systems, the revenue exposure measure appears to be a useful way to capture the effects of differential shocks across the income distribution and of tax structure on revenue changes. Having established this correspondence, we next use simulation analysis to examine the relative importance of tax structure versus changes in the tax base in explaining revenue exposure.

Table 3 compares the revenue exposure measure to a set of counterfactuals that standardize in turn the average tax rate, the degree of progressivity, and the economic shock, replacing state-specific values of each component by national averages across the 48 states. The standardization of progressivity substitutes the national average of the relative burdens on the top 5 percent and the next 15 percent of taxpayers, relative to the average burden in the state. The standardization of the economic shock replaces each state's actual changes in AGI per return for each income slice with the national average change for that slice.

Not surprisingly, the mean value of revenue exposure changes very little across simulations because the effects of the state-specific factors are averaged out. It is more informative to look at the standard deviations, which tell which factor most affects the 
Table 3 Alternative measures of potential revenue exposure

\begin{tabular}{|c|c|c|c|c|c|}
\hline $\begin{array}{l}\text { Potential change in total } \\
\text { tax revenue per return }\end{array}$ & Mean & Std Dev & Min & Max & $\begin{array}{c}\text { Rank correlation } \\
\text { with base case }\end{array}$ \\
\hline ase case $^{1}$ & -255 & 215 & -874 & 214 & \\
\hline \multicolumn{6}{|l|}{ Counterfactual simulations: } \\
\hline I (National average tax burden) ${ }^{2}$ & -251 & 201 & -781 & 253 & $.93^{* * *}$ \\
\hline I (National average tax progressivity) ${ }^{3}$ & -251 & 197 & -866 & 219 & $.95^{* * *}$ \\
\hline III (National average AGI change) ${ }^{4}$ & -262 & 85 & -421 & -78 & $.47^{* * *}$ \\
\hline III-A (National average AGI change-top 5\% only) $)^{5}$ & -262 & 126 & -516 & 17 & $.79^{* * *}$ \\
\hline III-B (National average AGI change-next $15 \%$ only) ${ }^{6}$ & -254 & 196 & -874 & 122 & $.99^{* * *}$ \\
\hline III-C (National average AGl change-bottom $80 \%$ only) ${ }^{7}$ & -255 & 186 & -852 & 98 & $.97^{* * *}$ \\
\hline ctual tax change per return & -138 & 582 & $-1,128$ & 2,596 & $.46^{* * *}$ \\
\hline \multicolumn{6}{|c|}{$\begin{array}{l}* * * \mathrm{p}<.01 . \\
\text { Notes: } \\
{ }^{1} \text { Potential change in total tax revenues per return, based on state-specific actual change in AGI. state-specific tax progressivity, } \\
\text { and state-specific average tax burden. } \\
\text { }{ }^{2} \text { Simulated potential change in tax revenues, based on state-specific actual change in AGl, state-specific tax progressivity, } \\
\text { but national average of states' average tax burdens. } \\
{ }^{3} \text { Simulated potential change in tax revenues, based on state-specific actual change in AGl, national average of states' } \\
\text { tax progressivity, and state-specific average tax burden. } \\
{ }^{4} \text { Simulated potential change in tax revenues, based on national average of states' change in AGI, state-specific tax } \\
\text { progressivity, and state-specific average tax burden. } \\
\text { 5Simulated potential change in tax revenues, based on national average of states' change in AGl for top } \mathbf{5 \% , ~ s t a t e - s p e c i f i c ~} \\
\text { tax progressivity, and state-specific average tax burden. }\end{array}$} \\
\hline
\end{tabular}

variance in exposure. The simulations show that imposing a uniform average tax rate (Simulation I), or uniform progressivity (Simulation II) have very little effect on the variation in fiscal exposure. However, imposing a uniform economic shock dramatically reduces the standard deviation (Simulation III). The coefficient of variation goes from 0.84 to 0.32 . This result suggests that variation across states in fiscal exposure to the Great Recession was due primarily to differences in the magnitude of the economic shock, as opposed to differing rates and structure of taxation.

To get a sense of the extent to which the change in the variance of revenue exposure under the simulations reflects a reduction in the absolute value of exposure among outliers, versus changes in rank order, the last column of Table 3 shows the Spearman rank correlation coefficients between revenue exposure and the various simulations. The large positive coefficients indicate that rank order is largely preserved under the simulations. The coefficient is close to one for the tax structure simulations. Though it is only half as large under the uniform AGI simulation (Simulation III), the coefficient is still significant at the one percent level. Thus, replacing the actual AGI changes with national averages reduces exposure among outliers, while still mostly preserving rank order in state revenue exposure.

To further decompose the economic shock, simulations III-A, III-B, and III-C in Table 3 replace one at time the actual change in AGI with the national average change for the top 5 percent (III-A), the next 15 percent (III-B), and the bottom 80 percent (III-C). The results show that standardizing the top 5 percent (III-A) produces a substantial reduction in the standard deviation (41 percent), while standardizing the other 
parts of the income distribution has little effect. This suggests that variation in the economic shock at the top of the income distribution is the key factor in explaining differences in the revenue exposure of states to the Great Recession. This suggestion is reinforced by the Spearman correlation coefficients between revenue exposure and the various simulations. Standardizing AGI change for the next 15 and bottom 80 percent does not change the ranking of states' revenue exposure $(\rho=+.99$ and $\rho=+.97$, respectively), but the ranking does change appreciably when AGI change is standardized for the top 5 percent alone $(\rho=+.79)$. Thus, a critical step in our analysis is to explain variations in the change in AGI among the top 5 percent. We turn next to this analysis.

\section{Capital gains, income inequality, and economic shocks}

In this section we present a set of regression models to explain the economic shock for the top 5 and next 15 percent of the AGI distribution as a function of income concentration and capital gains receipt. In the subsequent section we examine the role of changes in the tax base, together with the initial tax structure, in explaining the observed change in revenues.

The basic model to explain changes in the tax base by income level in a state is given by

$$
\Delta \mathrm{AGI}_{\mathrm{q}}=\mathrm{a}_{0}+\mathrm{a}_{1} \text { ShareAGI }_{\mathrm{q}}+\mathrm{a}_{2} \text { CapGainsShare }_{\mathrm{q}}+\mathrm{a}_{3} \text { Burden }_{\mathrm{q}},
$$

where $\mathrm{q}=$ top 5 denotes the top 5 percent and $\mathrm{q}=$ nxt 15 denotes the next 15 percent of the AGI distribution, $\triangle \mathrm{AGI}$ is the 2007-2009 change in AGI per return, ShareAGI is the share of total state AGI, CapGainsShare is the share of AGI that consisted of realized capital gains, and Burden is the tax burden, all for the $\mathrm{q}^{\text {th }}$ slice of the income distribution in 2007. (We suppress the subscripts indicating state and year to simplify the expression.)

We are not trying to explain all of the variation in the change in AGI with this model. Rather, we are interested in how the variation across states in the concentration of income at the top of the income distribution, and the variation in the share of capital gains in top incomes, contributed to the variation in the change in AGI at the top. Since capital gains took a bigger hit in 2007-2009 than other forms of income, we expect their importance to the upper income groups, together with the share of a state's aggregate income that is received by those groups, to be important in explaining the change in AGI at the top. We include the tax burden to test whether it is correlated with the change in AGI, controlling for the other two factors.

Estimation results are shown in Table 4. Column (1) shows that these three variables explain 85 percent of the variation in the income shock to the top 5 percent. Greater income concentration and a larger share of capital gains in top incomes at the outset of the recession were each associated with a bigger drop in AGI in the top 5 percent of the income distribution. It is notable that despite the relatively high correlation between income concentration and the capital gains share in the top 5 percent $(\rho=+.66)$, both income concentration and capital gains share are statistically significant and economically important. Evaluated at the mean change in AGI, a one percentage-point increase in the share of AGI in the top 5 percent implies a 7.6 percent greater reduction in top-5 AGI. For the capital gains share, the comparable change in AGI is 4.5 percent. These magnitudes indicate the strong relationship between income inequality and capital gains receipt and the cyclical behavior of a state's tax base. 
Table 4 Regression models for change in AGI per return by segment of the AGI distribution

\begin{tabular}{|c|c|c|}
\hline & (1) & (2) \\
\hline & $\begin{array}{c}\text { Change in AGI per return, } \\
\text { top } 5 \%\end{array}$ & $\begin{array}{c}\text { Change in AGI per return, } \\
\text { next } 15 \%\end{array}$ \\
\hline Share of top 5\% in AGl, 2007 & $-643475^{* * *}$ & \\
\hline t-statistic & {$[-8.17]$} & \\
\hline Cap gains share of AGI in top 5\% AGl, 2007 & $-378969^{* * *}$ & \\
\hline t-statistic & {$[-4.97]$} & \\
\hline Tax burden on top 5\% & $-381995^{* *}$ & \\
\hline t-statistic & {$[-2.36]$} & \\
\hline Share of next 15\% in AGl, 2007 & & 14802 \\
\hline t-statistic & & {$[0.66]$} \\
\hline Cap gains share of AGI in next 15\%, 2007 & & -15821 \\
\hline t-statistic & & {$[-0.29]$} \\
\hline Tax burden on next 15\% & & -24120 \\
\hline t-statistic & & {$[-0.89]$} \\
\hline Constant & $237904^{* * *}$ & -6972 \\
\hline t-statistic & {$[9.86]$} & {$[-0.93]$} \\
\hline No. of observations & 48 & 48 \\
\hline Adjusted R-squared & 0.847 & -0.040 \\
\hline
\end{tabular}

**p $<.05$, *** $p<.01$.

Column (1) indicates that, controlling for income concentration and capital gains, higher effective tax burdens on the top-5 AGI group across states are associated with greater declines in AGI. This result suggests that high tax burdens at the top may serve to magnify the actual fiscal effects of the economic shock. The direction of effect is consistent with our prior analysis of fiscal exposure, in which we found that replacing actual progressivity with national average progressivity, while keeping average tax burdens at their 2007 actual state levels, reduced the variation in exposure. However, the magnitude of the effect is small in both types of analysis. In the fiscal exposure analysis in Table 3, the standard deviation is reduced by 8.4 percent when we standardize progressivity; while in the regression analysis in Table 4, column (1), the proportion of the variation explained by the regression goes from .832 to .847 when the tax burden is added to the model (version without burden not shown).

The model explains 85 percent of the interstate variation in the income shock for the top 5 percent, but none of it for the next 15 percent (column 2). This suggests that the change in the tax base below the top 5 percent depends more on state-specific recessionary shocks to earnings and spending, as opposed to the national shock to capital gains realizations. Neither income concentration nor the capital-gains share in the next 15 percent has a significant effect. The insignificance of capital gains is no doubt because the capital-gains share of their income is so small (only 3 percent on average).

Recall from Section 3D that the single most important factor in explaining interstate variation in revenue exposure is the change in AGI among the top 5 percent of the AGI distribution. As shown in Table 4, the variation in top-5 AGI change is almost completely explained by differences in income concentration and capital gains receipt. Hence, imposing a uniform AGI change for the top 5 percent (as in Table 3, simulation III-A) is 
approximately equivalent to assuming a uniform concentration of income in the top 5 percent across states, and a uniform share of capital gains in the income of the top 5 percent. Having examined differential changes in AGI across states, in the next section of the paper we examine the effect of these differentials on actual changes in tax revenues.

\section{Actual revenue changes}

\section{A. Model}

In this section we model the relationship between the change in tax revenue and the key factors in revenue exposure - tax burdens and changes in AGI by slices of the income distribution - in progressively less restrictive ways. First, we combine the factors into a single measure of exposure - a sum of products, as shown in equation (7). Then, in order to analyze the effect of each factor in each product separately, we enter them in a multivariate linear model. Finally, we allow for interactions between the tax burden and change in AGI within each income slice.

The dependent variable in this analysis is the actual 2007-2009 change in state tax revenues per 2007 return, while the independent variables are the components of revenue exposure. The least restrictive specification is given by

$$
\Delta \text { Revenue }_{\mathrm{j}}=\mathrm{a}_{0}+\Sigma_{\mathrm{q}}\left(\mathrm{a}_{1} \cdot \Delta \mathrm{AGI}_{\mathrm{qj}}+\mathrm{a}_{2} \cdot \operatorname{Burden}_{\mathrm{qj}}+\mathrm{a} 3 \cdot \Delta \mathrm{AGI}_{\mathrm{qj}} \cdot \operatorname{Burden}_{\mathrm{qj}}\right)
$$

In (10), $j$ indexes the 48 contiguous states, while $q$ indexes the three slices of the AGI distribution: the top 5 percent, the next 15 percent, and the bottom 80 percent. The coefficients on $\triangle \mathrm{AGI}$ are expected to be positive, while the coefficients on the tax burden are expected to be negative. Coefficients on the interaction terms are expected to be positive; that is, the revenue impact of an economic shock at a given income level is expected to be greater, the higher the tax burden imposed at that income level.

The model in (10) does not include all of the variables that are related to the change in state tax revenue, because it is intended to estimate the effects of the factors in revenue exposure. The specification excludes policy responses - i.e., changes to tax rates or bases - because we lack state-specific data on these changes. Moreover, the revenue exposure measure is able to capture only part of the change in revenue from taxes with a strong export component, because we lack reliable estimates of exporting coefficients $^{22}$. Hence the regression is estimating the effect of fiscal exposure on revenue changes, including policy responses and export-related changes. Both of these factors are reflected in the error term. If these omitted factors are systematically more positive in states with greater potential revenue exposure, then negative estimates of the effect of revenue exposure on actual revenue changes may be biased toward zero ${ }^{23}$.

To get a sense of whether this is a serious problem - whether the offsets from policy and/or export are correlated with revenue exposure - we took the difference between actual tax changes and revenue exposure, and examined its correlation with the regressors in (10). None of the regressors for the top 5 percent was correlated with the difference at conventional significance levels ${ }^{24}$. This suggests that the potential bias from correlation of the error term with the regressors in (10) is unlikely to be very severe.

\section{B. Regression results}

Table 5 presents the analysis of the change in tax revenues. Model (1) is the most restrictive specification, including only the measure of potential revenue exposure as 
Table 5 Regression models for change in total tax revenue per return

\begin{tabular}{|c|c|c|c|}
\hline Variable & (1) & $(2)$ & (3) \\
\hline Potential Revenue Exposure & $1.015^{* * *}$ & & \\
\hline t-statistic & [2.74] & & \\
\hline Change in AGI per return, top 5\% & & -0.001 & $-0.020^{* * *}$ \\
\hline t-statistic & & {$[-0.69]$} & {$[-5.10]$} \\
\hline Change in AGl per return, next 15\% & & $0.092^{* *}$ & $0.575^{* * *}$ \\
\hline t-statistic & & [2.29] & [3.34] \\
\hline Change in AGl per return, bottom $80 \%$ & & 0.076 & 0.403 \\
\hline t-statistic & & {$[0.54]$} & {$[0.43]$} \\
\hline Tax burden on top 5\% & & -17077 & 16277 \\
\hline t-statistic & & {$[-1.35]$} & {$[1.41]$} \\
\hline Tax burden on next $15 \%$ & & 26227 & -9935 \\
\hline t-statistic & & [1.30] & {$[-0.50]$} \\
\hline Tax burden on next $80 \%$ & & $-23143^{*}$ & -16339 \\
\hline t-statistic & & {$[-1.90]$} & {$[-1.38]$} \\
\hline Change in AGl * Burden, top 5\% & & & $0.296^{* * *}$ \\
\hline t-statistic & & & {$[5.00]$} \\
\hline Change in AGl * Burden, next 15\% & & & $-6.116^{* * *}$ \\
\hline t-statistic & & & {$[-3.11]$} \\
\hline Change in AGl * Burden, bottom $80 \%$ & & & -3.114 \\
\hline t-statistic & & & {$[-0.34]$} \\
\hline Constant & 121 & $1217^{*}$ & 1181 \\
\hline t-statistic & [0.99] & [1.98] & {$[0.69]$} \\
\hline No. of observations & 48 & 48 & 48 \\
\hline Adjusted R-squared & 0.122 & 0.247 & 0.573 \\
\hline
\end{tabular}

${ }^{*} p<.10,{ }^{* *} p<.05,{ }^{* * *} p<.01$.

defined in (7) above. The results show a one-for-one relationship between potential exposure and the actual change in revenues, on average. However, potential revenue exposure is able to explain only a small portion of the interstate variation in revenue changes (adjusted $R^{2}=0.12$ ). This result is reflected in Figure 1 , which shows the relationship between these variables for states that are outliers in terms of progressivity or the magnitude of revenue changes.

The limited explanatory power of the fiscal exposure measure could reflect the possibility that changes in AGI and tax burdens by income level, reflecting both income and consumption taxes, do not adequately capture the transmission mechanism from recessionary shocks to revenue outcomes. Alternatively, the summary measure of revenue exposure may impose unwarranted restrictions on the effects of its individual components. Given the change in AGI in a particular slice of the income distribution, model (1) of Table 5 implies that a ten percent difference across states in the effective tax rate on that slice (e.g., from 5 to 5.5 percent) must result in a ten percent difference in the change in tax revenues generated from that slice (e.g., from - $\$ 100$ to $-\$ 110$ per return).

Models (2) and (3) of Table 5 successively relax these restrictions. Model (2) includes the various factors as separate covariates. In this specification the only AGI change that has a significant effect on revenue change is in the 80th-95th percentiles. Moreover, tax 
burdens on the top 20 percent of the distribution are insignificant, while the burden on the bottom 80 percent has a negative effect, which is significant at the 10 percent level. The explanatory power of the regression, while greater than in model (1), is still weak.

Model (3) allows for interaction effects between tax burdens and changes in the tax base. This more than doubles the overall explanatory power of the regressions (from .25 to .57). The interaction terms reveal that the effect on revenue change of the tax burden on the top 5 percent depends on the magnitude of the decrease in the base. A higher tax rate is associated with a larger decrease (or smaller gain) in tax revenues for the 36 states with drops in AGI for the top 5 percent of $\$ 55,000$ or more. The results for these states are consistent with the hypothesis that the higher the top rate, the greater the fiscal shock that results from an income shock. However, among the 12 states with a decrease in income for the top 5 percent of less than $\$ 55,000$, the higher the top tax rate, the smaller the decrease (or the larger the gain) in revenue $\mathrm{e}^{25}$. Thus, for states whose income shock was below this threshold, a higher tax rate at the top did not increase the fiscal risk from the Great Recession.

Conversely, the revenue effect of an income shock to the top of the income distribution is conditioned by the initial tax burden. For the 24 states with burdens on the top 5 percent of 6.9 percent or more, a larger negative income shock at the top led to a greater decrease (or smaller gain) in revenue. But among the other 24 states, which had burdens on the top 5 percent of less than 6.9 percent, a larger negative income shock to this top group led to a smaller loss (or bigger gain) in revenue.

It is widely claimed that more progressive states, because they rely more heavily on the personal income tax, face more volatility in their revenue streams over the business cycle $^{26}$. Consistent with this claim, equation (3) in Table 5 indicates that at the mean change in top-5 AGI $(-\$ 84,000)$, a higher tax burden is associated with a larger decrease in revenues. Moreover, when we put together the effects of tax structure and base shock, the recession's effect on state revenues was substantially magnified in those states with both high tax burdens and large income shocks at the top of the income distribution.

The key result from our research is that empirically, in contrast to this general view, the progressivity-volatility link is weak. Only three states - California, New York, and New Jersey - had both high tax rates on the top 5 percent and large negative income shocks ${ }^{27}$. The large income shocks in these three states are related to the very high degree of income concentration and, in two of the states, the high relative importance of capital gains ${ }^{28}$. To be sure, these are important states, raising 28 percent of all state tax revenues in $2007^{29}$. No other state was even in the top quartile of both effects. Among all states, the simple correlation between the tax burden and change in AGI for the top 5 percent is +.165 , the positive sign indicating that states with larger negative shocks to top incomes tended to have smaller tax burdens on this group, on average. Excluding California, New York, and New Jersey, the mean burden on the top 5 percent for the other 15 states with larger-than-average drops in their AGI is .055, whereas the national average is .066 .

The very low correlation between the tax burdens and income shocks to the top 5 percent reflects the negative correlation between the tax burden and the principal determinants of the change in AGI at the top: income concentration $(\rho=-.24)$ and capital gains receipt $(\rho=-.47)$. As noted in Section 4 , these variables explain most of the variation in AGI change for the top 5 percent. 
The revenue effect of a higher tax burden on the 80th-95th percentiles is the opposite of the effect for the top 5 percent. The negative coefficient on the interaction term (Table 5, column 3, row 9) implies that the greater the decrease in AGI, the smaller the decrease (or the larger the increase) in revenue corresponding to a higher tax rate on the next 15 percent. Evaluated at the mean change in AGI for this group (-\$5,257 per return), states with higher tax burdens on the 80th-95th percentiles had smaller decreases in tax revenue, or actual increases ${ }^{30}$. However, because the tax burden is virtually uncorrelated with the change in AGI for the next 15 percent $(\rho=-0.112$, $p$-value $=.45)$, the overall effect of higher next-15 tax burdens on revenue changes is muted.

The ITEP analysis indicates a very strong positive correlation between the burdens on adjacent segments of the income distribution. The correlation between the burdens on the top 5 percent and the next 15 percent is .92 . This strong correlation means that higher burdens on the next 15 percent in some states than others are not an indication of greater tax regressivity at the top of the income distribution. Hence, the revenuedampening effect of higher burdens on the next 15 percent cannot be interpreted as an effect of regressivity on tax volatility. We suspect that the result is related to the very weak correlation between next-15 burdens and changes in AGI.

The results from model (3) of Table 5 suggest that the overall relationship between tax progressivity and revenue volatility is weak and even counterintuitive. Higher tax burdens at the very top of the income distribution do increase the potential fiscal risk from recession in those states where income at the top is very volatile. However, empirically the actual effect is small on average, because most states with high exposure at the top do not impose high tax burdens on that group. The three states with the highest burdens on the top 5 percent - California, New York, and New Jersey - also had very large negative income shocks, due to the concentration of income and - in California and New York - large shares of capital gains at the top; but they are exceptional cases. Most states with large income shocks to the top 5 percent have below-average tax burdens on this group, which reduces the impact on tax revenues. Moreover, in the next 15 percent of the distribution, higher tax burdens are associated with reduced revenue volatility at the mean income shock. Thus higher burdens in the top 20 percent of the income distribution, which are associated with a less regressive tax structure, did not increase overall tax volatility during the Great Recession.

\section{Conclusion}

The impact of the Great Recession on state tax revenues has been severe, with the depth and persistence of the decline greater than any other downturn in the post-war period. The innovation of this paper is to analyze this downturn, not in terms of the behavior of individual taxes, but in terms of the distribution of income and of tax burdens. This approach allows us to determine the extent to which the revenue decline is influenced by income inequality and volatility, compared with the progressivity of state tax structure. We hypothesized that more progressive states are more vulnerable to revenue losses in economic downturns, and that this greater vulnerability has been amplified by secular changes in the income distribution.

To apply these hypotheses to the Great Recession, we use estimates of state-specific tax burdens and changes in AGI by slice of the income distribution to construct a measure of potential revenue exposure for each state, and examine how much the 
dispersion in this measure is affected by the economic shock, tax progressivity, and average tax burdens. This exercise suggests that the dominant factor in explaining the variation in potential revenue exposure is the economic shock to the tax base in a state, particularly among the top 5 percent of filing units, as opposed to variations in tax burdens or progressivity.

We then analyze the determinants of the economic shock. We find that the both the concentration of income and the share of capital gains in the income of high-income taxpayers are important determinants of the economic shock to states. Evaluated at the mean, a one percentage-point increase in income concentration leads to a 7.7 percent greater decrease in AGI. A one standard-deviation increase (about five percentage points) leads to a 38 percent increase in the economic shock. A one standard-deviation increase in the capital-gains share (about five percentage points) leads to a 23 percent increase. Given the range across states, these effects are large enough to have a significant effect on the volatility of the tax base, and potentially on the volatility of revenues.

We also estimate a multiple regression model of actual revenue changes over the recessionary period 2007-2009, as a function of the components of revenue exposure and their interactions. Specified as a single variable, potential revenue exposure explains only a small portion of the variation in actual changes. However, when we decompose exposure into its components and include interaction terms, more than half of the variation in actual revenue change is explained. We find that both the direction and the magnitude of their effects depend on interactions between the tax burden and the AGI change.

The revenue effect of an income shock to the top of the income distribution is conditioned by the initial tax burden. In the Great Recession the average effect of differences in tax progressivity was small. For states with above-median tax burdens, a larger income shock led to a greater decrease in revenue; but for the remaining states, a higher tax burden was associated with a smaller decrease in revenues. Hence, while states with a high degree of income concentration and/or dependence on capital gains are especially vulnerable to volatility in the tax base, the resulting large changes in AGI at the top of the income distribution do not necessarily translate into sharper drops in tax revenue. This is because income volatility and tax progressivity are weakly correlated across U.S. states. Hence, with a few important exceptions, the potential revenue exposure implied by large drops in the top end of the income-tax base tends not to be reinforced by high effective tax rates at the top.

These findings hold despite the fact that the most progressive states did on average tend to have larger tax declines than the most regressive states. However, there are also some notable counterexamples. For example, Florida and Nevada suffered among the largest reductions in state tax revenues, both in absolute and percentage terms, despite highly regressive tax systems. These states were subject to high tax-base volatility at the top, due to very unequal income distributions and high capital gains receipts. Though the lack of an income tax in both of these states insulated them from the direct effects of declines in capital-gains income, this volatility-reducing effect was outweighed by the decline in tourism and construction-related consumption taxes.

The impact of the recession on state tax revenues operates through two different channels. The first is through the national impact of the sharp decline in stock market valuations, and the attendant collapse in realized capital gains. State tax bases are 
affected by this component in proportion to their pre-recession reliance on capital gains income, which in turn is associated with the degree of income concentration. In a small number of states, progressive tax structures amplified the fiscal impact of large drops in capital gains income. However, our regression results suggest that in a larger group of states, tax structures served to dampen the revenue impact of the change in capital gains.

The second channel through which the national recession impacts state tax revenues is through its differential effect on output and employment by state. This channel has a greater impact on incomes below the top 5 percent of the distribution than in the top 5 percent. Our findings for this group are surprising. Higher tax burdens on the 80th to 95th percentiles of their income distributions, which are characteristic of more progressive state tax systems, tended to mitigate rather than exacerbate recession-induced declines in tax revenues.

Revenue volatility is often presented as an argument against using more progressive income tax policy to address rising income inequality. Our analysis of the effects on state tax revenues of the Great Recession does not support this argument. In this very steep downturn, regressive taxation failed to insulate states from revenue shocks, while for most states greater tax progressivity did not amplify revenue shocks. We emphasize that our findings are based on a single, albeit very severe, cyclical downturn. However, the methods developed in this paper can and should be applied to the analysis of other recessions, to determine the generalizability of our findings.

\section{Endnotes}

${ }^{1}$ In real terms, state tax revenues in 2012 were still 5 percent lower than in 2008. In the 2001 recession, nominal tax revenues declined for only one year, showing a 4.3 percent drop from 2001 to 2002. By 2004, three years after the onset of the recession, nominal revenues were 5.7 percent higher than the previous peak in 2001. A year later, in 2005 , tax revenues were 16.3 percent higher than in the year of the recession. In the double-dip recession of 1980-1982, state tax revenues continued to grow in nominal terms throughout the recession and its aftermath. By 1985, five years after the onset of the first of the double-dip recessions (and three years after the official end of the second), state tax collections were up 57.4 percent.

${ }^{2}$ Through 2011, about 40 percent of the decline in state revenues was offset by increased federal assistance under the American Recovery and Reinvestment Act of 2009 (ARRA). Nearly all of the ARRA funds for fiscal relief to states were scheduled to be spent by June of 2011.

${ }^{3}$ Hawaii and Alaska are excluded from the analysis because these states, by virtue of their geographic separation from the others, are not subject to the same pressure of fiscal competition as the other states, and because both have fiscal structures that are very different from the other states. Almost all of Alaska's tax revenues come from severance taxes on oil, while Hawaii has a disproportional reliance on state versus local taxation.

${ }^{4}$ Dye (2004) discusses the fact that the decline in state tax revenues in the 2001 recession was very large relative to the magnitude of the economic shock. He attributes the greater volatility of state tax revenues to the disproportionate growth in capital gains and other non-wage income in the late 1990s. Moreover, between 1993 and 2010, 
average real family income grew by 58 percent for the top one percent of families, versus 6.4 percent for the other 99 percent of families (Saez 2012).

${ }^{5}$ In 2007, 38 percent of capital-gains realizations were received by the top one tenth of one percent of taxpayers (Lurie and Pearce 2012).

${ }^{6}$ Between 2007 and 2009, average real family income fell by 17 percent while real income for the top percentile fell by 36 percent (Saez 2012). Aggregate capital-gains realizations plummeted from $\$ 913$ billion in 2007 to $\$ 48$ billion in 2009 (Lurie and Pearce 2012).

${ }^{7}$ A similarly sharp change in realizations occurred in the 2001 recession, dropping from $\$ 700$ billion in 2000 to $\$ 126$ billion in 2002 (Lurie and Pearce 2012).

${ }^{8}$ The data source and methodology for capital-gains shares is described below in Section 3C.

${ }^{9}$ Incidence assumptions and methodology used to compute tax burdens are discussed in Section 3C.

${ }^{10}$ The structure of the income tax varies widely across states. Of the 41 states that use broad-based income taxation, 19 states have either a flat rate or tax most income at a single rate. For the rest of the income-tax states, there is considerable variation in both the top rate and the degree of graduation (Dye 2004).

${ }^{11}$ Dietz et al. (2010) argue that reliance on more cyclically sensitive taxes has increased the budgetary exposure of particular states to cyclical economic fluctuations. Boyd (2010) makes a similar point in terms of the recovery from the Great Recession.

${ }^{12}$ For example, New York reduced its exemption for clothing from its sales tax base, while Michigan increased the effective income tax rate on low-income taxpayers by reducing the size of the state supplement to the federal Earned Income Tax Credit. As of July 2009, 30 states had increased at least one state tax rate, as compared to their pre-recession level (Center on Budget and Policy Priorities 2010).

${ }^{13}$ The ITEP model breaks the top quintile of tax burdens into the top one percent, the next four percent, and the next 15 percent.

${ }^{14}$ While for most states this omission makes little difference, for those few states with large revenues from mineral taxation (severance taxes) or high levels of tourism, the disparity between average tax burdens as measured by the ITEP and tax collections as a fraction of state personal income could be substantial.

${ }^{15}$ Linear interpolation implicitly assumes that the AGI and capital gains amounts are uniformly distributed within an AGI bracket. However, we infer from the overall shapes of the AGI and capital gains distributions that AGI is concentrated at the lower end and capital gains at the upper end of each bracket. Therefore, linear interpolation overstates AGI and understates capital gains in the top 5 percent of returns, and therefore understates the capital-gains share of AGI in that part of the income distribution. Unfortunately, the published IRS data are in broad income brackets, which do not permit a more refined interpolation.

${ }^{16}$ In 2007 and 2009 fewer than 5 percent of returns were in the top AGI bracket (\$200,000 or above) in every state but two (New Jersey, with 5.1 percent in 2007 and Connecticut, with 5.1 percent in 2009). We treat the top AGI bracket as equivalent to the top 5 percent in New Jersey in 2007 and Connecticut in 2009.

${ }^{17}$ Actual state tax revenues come from U.S. Census Bureau, various years.

${ }^{18}$ The largest percentage decline in state revenue was in Arizona (-23 percent), while the largest increase was in Wyoming (+36 percent). The state at the 10th percentile of 
actual changes in revenue per return had a decline of 12.6 percent, while the state at the 90th percentile had an increase of 24 percent.

${ }^{19}$ The state at the 10th percentile of revenue exposure, California, was at risk for a revenue decrease of $\$ 617$ per return, while at the 90th percentile West Virginia was at risk for a $\$ 74$ increase.

${ }^{20}$ The Census of Governments defines severance taxes as "Taxes imposed distinctively on removal of natural products (e.g. oil, gas, other minerals, timber, fish, etc.) from land or water and measured by value or quantity of products removed or sold".

${ }^{21}$ The difference between the two states is that New York, unlike California, implemented an important policy offset in this period, raising the top marginal income tax rate for taxable income exceeding $\$ 200,000$ (single filers). Starting on January 1, 2009, marginal tax rates were set at 7.85 percent for taxable income exceeding $\$ 300,000$ (married filing jointly), and 8.97 percent for income exceeding $\$ 500,000$. Prior rates were 6.85 percent for taxable income exceeding $\$ 40,000$ (Tax Foundation, 2013). It is worth noting that the standard deviation of revenue exposure for the income tax alone is much closer to the standard deviation of actual income tax revenues than is the case for all taxes.

${ }^{22}$ States are able to export severance taxes because mineral extractions are typically sold on national or international markets. For states that depend heavily on tourism, taxes on consumption are likely to have a higher than average export component. To the extent that changes in extraction activity or tourism are translated into changes in domestic income, the effects will be at least partially captured by changes in the tax base (AGI). Hence, at least some portion of the revenue impact of windfall gains or losses in severance taxes or tourism-related revenues will be captured by the model.

${ }^{23}$ Evidence for such an offset comes from Poterba (1994) who finds that in the 19881992 period offsetting state tax responses to unexpected negative deficit shocks were proportional to the magnitude of the shock. Poterba finds that there is an increase in states taxes after two years approximately equal to the shock.

${ }^{24}$ At the ten percent level of significance, changes in top 5 percent AGI were positively correlated (Pearson correlation coefficient) with the offset, while changes in the next 15 percent were negatively correlated with it.

${ }^{25}$ Controlling for the average tax burden in a state and the burdens on the other percentiles, the effect on revenue of a 100 percentage-point increase in the tax burden (i. e., from 0 to 1$)$ on the top 5 percent equals $\left(16277+.296 \cdot \Delta \mathrm{AGI}_{\text {top } 5}\right)$. Setting this expression equal to zero implies the results given in the text.

${ }^{26} \mathrm{~A}$ typical example of this claim is given by the Tax Foundation (2013), in their response to the Institute for Taxation and Economic Policy release of their 2013 distributional analysis for states (ITEP 2013).

${ }^{27}$ These three states had tax burdens on the top 5 percent which were the highest among all states, and the fourth, seventh, and eighth largest decreases in top-5 AGI.

${ }^{28}$ In 2007, the shares of AGI received by the top 5 percent in New York, California, and New Jersey were $.47, .39$, and .38 respectively, as compared to the mean share of .34. Capital-gains shares of income in the top 5 percent in New York and California were .26 and .24, versus a national average of .21. However, New Jersey's capital-gains share (.17) was actually lower than the national average.

To get a sense of the potential impact of these factors on actual revenue change in California, the regression coefficients in column (1) in Table 4 imply that if California 
were to have national average income concentration and capital gains receipt, its AGI reduction in the top 5 percent would have gone from $\$ 150,043$ to $\$ 104,834$, or about a 30 percent smaller income shock. Applying this smaller change to the revenue coefficients from equation (3) in Table 5, the impact on predicted revenues via the top 5 percent would in turn have been reduced by $\$ 376$ (from $-\$ 1249$ to $-\$ 873$ ), or about 30 percent. This predicted change is a little less than half of the actual reduction in tax revenues in California ( $\$ 376 / \$ 780)$. If the capital-gains share in the top 5 percent were set equal to the national average, but income concentration in California were unchanged, the smaller top 5 percent AGI change would have cut California's revenue loss by only 13 percent $(\$ 101 / \$ 780)$.

${ }^{29}$ Note however that in one of the three high-exposure states, New York, tax revenues actually increased. This is because the state increased the top marginal tax rates, thus offsetting its large potential revenue exposure.

${ }^{30}$ From column (3) of Table 5, the effect of a one-unit increase in Burden ${ }_{\text {nxt15 }}$ is given by $\left(-9935-6.116 \cdot \Delta \mathrm{AGI}_{\mathrm{nxt15}}\right)$. Setting this term to zero implies that if the decrease in AGI for the 80th-95th percentiles is larger than $\$ 1625$, a higher tax burden on the next 15 percent is associated with a smaller reduction in state tax revenues, ceteris paribus.

Competing interests

The IZA Journal of Labor Policy is committed to the IZA Guiding Principles of Research Integrity. The authors declare that they have observed these principles.

\section{Acknowledgements \\ We would like to thank the Russell Sage Foundation for their support, and the Citizens for Tax Justice Institute for Taxation and Economic Policy for making available to us the data from their state tax simulation model. For helpful comments we thank Richard Dye, and participants in the IZA Workshop on the Future of Labor: The Effects of the Economic Crisis on the Labor Market, Unemployment and Income Distribution, Bonn, Germany, February 2013, and the Russell Sage Foundation seminar Great Recession Initiative- State and Political Responses, Russell Sage Foundation, March 2013. We would also like to thank the referee and editor of the IZA Journal of Labor Policy for detailed comments. Responsible editor: David Neumark}

\section{Author details}

${ }^{1}$ Hunter College and the Graduate Center, CUNY, New York, USA. ${ }^{2}$ Hunter College, CUNY, New York, USA. ${ }^{3}$ Ithaca College, Ithaca, New York, USA.

Received: 20 April 2013 Accepted: 19 January 2014

Published: 12 Feb 2014

\section{References}

Boyd D (2010) Recession recovery and state and local finances. Paper presented at conference on The Effects of the Housing Crisis on State and Local Governments, the Urban Institute and the Lincoln Institute, Washington DC, May 2010

Bruce D, Fox W, Tuttle MH (2006) Tax base elasticities: a multi-state analysis of long-run and short-run dynamics. Southern Econ J 73(2):315-41

Center on Budget and Policy Priorities (2010) State tax changes in response to the recession. Available via http://www. cbpp.org/files/3-8-10sfp.pdf. Accessed 13 Jan 2014

Chernick H (2005) On the determinants of subnational tax progressivity in the U.S. Natl Tax J 58:93-112

Chernick H, Reschovsky A (1997) Who pays the gasoline tax? Natl Tax J 50:233-259

Dietz R, Haughwout AF, Steindel C (2010) The recession's impact on the state budgets of New York and New Jersey. New York Federal Reserve Bank Current Issues in Economics and Finance 16(6):1-11

Dye R (2004) State revenue cyclicality. Natl Tax J 57:133-145

Dye R, McGuire T (1991) Growth and variability of state individual income and general sales taxes. Natl Tax J 44:55-66

Holcombe R, Sobel R (1996) Growth and variability in state tax revenue: an anatomy of state fiscal crises. Greenwood Press, Westport

Institute for Taxation and Economic Policy (2009) Who pays? A distributional analysis of the tax systems in all 50 states, 3rd edition. Available via http://www.itepnet.org/state_reports/whopays.php. Accessed 13 Jan 2014

Institute for Taxation and Economic Policy (2011) A capital idea: repealing state tax breaks for capital gains would ease budget woes and improve tax fairness. Available via http://itepnet.org/pdf/capitalidea0111.pdf. Accessed 13 Jan 2014

Institute on Taxation and Economic Policy (2013) Who pays? A distributional analysis of the tax systems in all 50 states, 4th edition. Available via http://www.itep.org/pdf/whopaysreport.pdf. Accessed 13 Jan 2014 
Internal Revenue Service (various years) SOI Tax Stats - Historic Table 2. Available via http://www.irs.gov/uac/SOI-TaxStats-Individual-Income-Tax-Returns-Publication-1304-(Complete-Report). Accessed 13 Jan 2014

Lurie I, Pearce J (2012) Are capital gains realization dynamics in the Great Recession different than the early 2000's recession? A Markov chain analysis using tax data. Office of Tax Analysis, U.S. Department of Treasury, Washington

Poterba JM (1994) State responses to fiscal crises: the effects of budgetary institutions and politics. J Pol Econ 102(4):799-821

Saez E (2012) Striking it richer: the evolution of top incomes in the United States (Updated with 2009 and 2010 estimates). Available via http://elsa.berkeley.edu/ saez/saez-UStopincomes-2010.pdf. Accessed 13 Jan 2014

Seegert N (2012) Optimal taxation with volatility: a theoretical and empirical decomposition. Available via http://wwwpersonal.umich.edu/ seegert/papers/OptimalTaxationwithVolatility_Seegert.pdf. Accessed 13 Jan 2014

Tax Foundation (2013) Comments on Who pays: a distributional analysis of the tax systems in all 50 states. Available via http://taxfoundation.org/article/comments-who-pays-distributional-analysis-tax-systems-all-50-states. Accessed 13 Jan 2014

U.S. Census Bureau (various years) State government tax collections. Available via http://www.census.gov/govs/statetax/. Accessed 13 Jan 2014

U.S. Dept of Commerce (2009) Bureau of Economic Analysis. Available via http://bea.gov/iTable/iTable.cfm?ReqID=9\& step=1\#reqid=9\&step=3\&isuri=1\&910=x\&911=0\&903=63\&904=2007\&905=2009\&906=a. Accessed 15 Jan 2014

10.1186/2193-9004-3-3

Cite this article as: Chernick et al:: Tax structure and revenue instability: the Great Recession and the states. IZA Journal of Labor Policy 2014, 3:3

Submit your manuscript to a SpringerOpen ${ }^{\circ}$ journal and benefit from:

- Convenient online submission

- Rigorous peer review

- Immediate publication on acceptance

- Open access: articles freely available online

- High visibility within the field

- Retaining the copyright to your article

Submit your next manuscript at $\gg$ springeropen.com 